Review

\title{
Human T-Lymphotropic Virus Type 1 (HTLV-1) and Regulatory T Cells in HTLV-1-Associated Neuroinflammatory Disease
}

\author{
Natsumi Araya ${ }^{1}$, Tomoo Sato ${ }^{1}$, Naoko Yagishita ${ }^{1}$, Hitoshi Ando ${ }^{1}$, Atae Utsunomiya ${ }^{2}$, \\ Steven Jacobson ${ }^{3}$ and Yoshihisa Yamano ${ }^{1, *}$
}

1 Department of Rare Diseases Research, Institute of Medical Science, School of Medicine, St. Marianna University, Kawasaki 216-8511, Japan; E-Mails: araya@marianna-u.ac.jp (N.A.); tomoo@marianna-u.ac.jp (T.S.); yagi@marianna-u.ac.jp (N.Y.); hando@marianna-u.ac.jp (H.A.)

2 Department of Hematology, Imamura Bun-in Hospital, Kagoshima 890-0064, Japan;

E-Mail: autsunomiya@jiaikai.jp

3 Viral Immunology Section, Neuroimmunology Branch, National Institute of Neurological Disorders and Stroke, National Institutes of Health, Bethesda, MD 20892, USA;

E-Mail: jacobsons@ninds.nih.gov

* Author to whom correspondence should be addressed; E-Mail: yyamano@marianna-u.ac.jp; Tel.: +81-44-977-8111; Fax: +81-44-977-9772.

Received: 2 June 2011; in revised form: 13 August 2011 / Accepted: 16 August 2011 / Published: 25 August 2011

Abstract: Human T-lymphotropic virus type 1 (HTLV-1) is a retrovirus that is the causative agent of adult $\mathrm{T}$ cell leukemia/lymphoma (ATL) and associated with multiorgan inflammatory disorders, including HTLV-1-associated myelopathy/tropical spastic paraparesis (HAM/TSP) and uveitis. HTLV-1-infected T cells have been hypothesized to contribute to the development of these disorders, although the precise mechanisms are not well understood. HTLV-1 primarily infects $\mathrm{CD}^{+} \mathrm{T}$ helper (Th) cells that play a central role in adaptive immune responses. Based on their functions, patterns of cytokine secretion, and expression of specific transcription factors and chemokine receptors, Th cells that are differentiated from naïve $\mathrm{CD} 4^{+} \mathrm{T}$ cells are classified into four major lineages: $\mathrm{Th} 1, \mathrm{Th} 2$, Th17, and $\mathrm{T}$ regulatory (Treg) cells. The $\mathrm{CD} 4^{+} \mathrm{CD} 25^{+} \mathrm{CCR} 4^{+} \mathrm{T}$ cell population, which consists primarily of suppressive T cell subsets, such as the Treg and Th2 subsets in healthy individuals, is the predominant viral reservoir of HTLV-1 in both ATL and $\mathrm{HAM}$ /TSP patients. Interestingly, $\mathrm{CD} 4^{+} \mathrm{CD} 25^{+} \mathrm{CCR} 4^{+} \mathrm{T}$ cells become Th1-like cells in 
HAM/TSP patients, as evidenced by their overproduction of IFN- $\gamma$, suggesting that HTLV-1 may intracellularly induce $\mathrm{T}$ cell plasticity from Treg to IFN- $\gamma^{+} \mathrm{T}$ cells. This review examines the recent research into the association between HTLV-1 and Treg cells that has greatly enhanced understanding of the pathogenic mechanisms underlying immune dysregulation in HTLV-1-associated neuroinflammatory disease.

Keywords: HTLV-1; HAM/TSP; ATL; $\mathrm{CD} 4{ }^{+} \mathrm{CD} 25^{+} \mathrm{CCR} 4^{+} \mathrm{T}$ cell; regulatory $\mathrm{T}$ cell; exFoxp $3^{+}$cell; inflammation; immune-dysfunction

\section{Introduction}

Human T-lymphotropic virus type $1(\mathrm{HTLV}-1)$ is a retrovirus associated with chronic, persistent infection of human T cells. HTLV-1 infection is endemic in Japan, the Caribbean, and part of South America, Africa, the Middle East, and Melanesia [1]. Studies conducted in HTLV-1 endemic areas have demonstrated that HTLV-1 infection is associated with a variety of human diseases, including an aggressive mature $\mathrm{T}$ cell malignancy termed adult T-cell leukemia (ATL) [2], which is defined as neoplastic growth of HTLV-1-infected T cells. HTLV-1 is also associated with non-neoplastic inflammatory conditions such as HTLV-1-associated myelopathy/tropical spastic paraparesis (HAM/TSP) [3,4], uveitis [5], Sjögren syndrome [6], bronchoalveolitis, arthritis [7], and polymyositis [8], where high tissue concentrations of HTLV-1 infected T lymphocytes have been observed. Importantly, some patients have more than one of these HTLV-1-associated inflammatory conditions [9].

Although HTLV-1-associated disorders have been extensively studied, the exact mechanism by which HTLV-1 induces these inflammatory conditions is not completely understood. The proviral load of HTLV-1 may contribute to development of HTLV-1-associated inflammatory conditions, since the number of HTLV-1-infected $\mathrm{T}$ cells circulating in the peripheral blood is higher in patients with HAM/TSP than in asymptomatic HTLV-1-infected individuals [10,11], and is even higher in the cerebrospinal fluid of patients with HAM/TSP [12]. In HAM/TSP patients, the proviral load correlates with not only the percentage of activated $\mathrm{CD}^{+} \mathrm{T}$ cells but also with that of HTLV-1-specific CD8 ${ }^{+}$ cytotoxic T lymphocytes (CTLs) [11,13]. These HTLV-1-specific CTLs produce various cytokines, such as IFN- $\gamma$ and TNF- $\alpha$, that may suppress viral replication and kill infected cells and/or promote bystander activation and killing of nearby resident cells in the central nervous system (CNS) [14-17]. In addition, increased viral expression, particularly of the transactivating viral gene encoding HTLV-1 Tax, has also been hypothesized to play a role in HTLV-1 disease progression [11,12]. Transgenic mice expressing HTLV-1 Tax develop an inflammatory arthropathy [18], and transgenic rats expressing HTLV-1 env-pX develop destructive arthropathy, Sjögren syndrome, vasculitis, and polymyositis [19]. These findings support the hypothesis that HTLV-1 $\operatorname{tax}$ is one of the exogenous retrovirus genes responsible for immune dysregulation.

HTLV-1 Tax is a transactivator/oncoprotein that has potent effects on infected $\mathrm{T}$ cells, including activation of nuclear factor(NF)- $\mathrm{BB}$ [20] with subsequent enhancement of cell activation and proliferation and expression of various cellular genes, such as IL-2 [21], the $\alpha$-chain of the IL-2 receptor (IL-2R $\alpha$ ) [22], IL-15 [23], and IL-15R $\alpha$ [24]. Such virus-induced intracellular activation may 
directly contributes to $\mathrm{T}$ cell activation and the ex vivo $\mathrm{T}$ cell proliferation observed in patients with HAM/TSP [25]. These findings suggest that invasion by HTLV-1-infected T cells, together with viral gene expression and cellular-signaling mechanisms, trigger a strong virus-specific immune response and increased proinflammatory cytokine production, leading to CNS inflammation and autologous tissue damage. However, the precise mechanisms underlying the induction of immune activation by HTLV-1-infected T cells are not well understood.

\section{HTLV-1 and Regulatory T Cells}

The recent discovery of regulatory $\mathrm{T}$ cells (Treg cells) has generated new opportunities for and increased interest in elucidating the above mentioned mechanisms. In healthy individuals, the Treg cells, a subset of $\mathrm{CD} 4^{+} \mathrm{CD} 25^{+} \mathrm{T}$ cells, play a key role in maintaining immune system homeostasis by suppressing the proliferation of and cytokine production by pathogenic T cells [26]. Although Treg cells are phenotypically similar to activated $\mathrm{T}$ cells, they can be identified ex vivo by their intracellular expression of the transcriptional regulator Foxp3 [27], which is critical in the development and functioning of Treg cells in both mice and humans. Significant reductions in Foxp3 expression and/or Treg cell function have been observed in patients with several types of human autoimmune diseases [28], suggesting that defects in Foxp3 expression and/or Treg functioning may precipitate loss of immunological tolerance. $\mathrm{CD} 4{ }^{+} \mathrm{CD} 25^{+} \mathrm{T}$ cells are also the predominant viral reservoir in the peripheral blood of HTLV-1-infected individuals [29]. Recently, significant reductions in Foxp3 expression and Treg cell function have been observed in $\mathrm{CD} 4{ }^{+} \mathrm{CD} 25^{+} \mathrm{T}$ cells from patients with HAM/TSP [30-34]. Furthermore, decreased expression levels of CTL antigen-4 (CTLA-4), a Treg-associated immune-suppressive molecule, and glucocorticoid-induced tumor necrosis factor receptor-related protein (GITR) have also been observed on the $\mathrm{CD} 4{ }^{+} \mathrm{CD} 25^{+} \mathrm{T}$ cells of HAM/TSP patients [30,34]. Notably, overexpression of HTLV-1 Tax has been observed to reduce Foxp3 expression and inhibit the suppressive function of Treg cells in vitro [30]. Furthermore, because of a Tax-induced defect in TGF- $\beta$ signaling, Foxp3 expression was decreased and Treg functions were impaired in patients with HAM/TSP [35]. Recently, significantly decreased numbers of $\mathrm{CD} 4{ }^{+} \mathrm{CD} 25^{+} \mathrm{Foxp}^{+}{ }^{+}$Treg cells were observed in transgenic mice expressing HTLV-1 Tax that develop an inflammatory arthropathy [36]. In addition, increased viral expression of the HTLV-1 bZIP factor (HBZ) gene encoding the minus strand of HTLV-1 has also been suggested to play a role in HTLV-1 disease progression [37], and $\mathrm{CD}^{+} \mathrm{Foxp}^{+}$Treg cells in HBZ transgenic mice were functionally impaired [38]. These findings indicate that HTLV-1-induced dysfunctioning of $\mathrm{CD} 4{ }^{+} \mathrm{CD} 25^{+}$Treg cells may be one of the mechanisms underlying the induction of immune activation by HTLV-1-infected T cells.

In contrast to the decreased expression of Foxp 3 in $\mathrm{CD} 4{ }^{+} \mathrm{CD} 25^{+} \mathrm{T}$ cells observed in HAM/TSP patients [30-34], most $\mathrm{CD} 4{ }^{+} \mathrm{CD} 25^{+}$ATL cells have been shown to express Foxp3 in patients with ATL $[39,40]$. Therefore, it has been hypothesized that ATL cells may be derived from Treg cells [41]. Interestingly, some ATL cells exhibit immunosuppressive functions similar to those of Treg cells, which may contribute to clinically observed cellular immunodeficiency in ATL patients [41-43], although some of these ATL cells lose this regulatory function [44]. 


\section{HTLV-1 and CD4 ${ }^{+} \mathrm{CD}^{2} 5^{+} \mathrm{CCR} 4^{+} \mathrm{T}$ Cells}

Although HTLV-1 has been reported to infect a number of cell types both in vitro and in vivo [29,45-49], $\mathrm{CD}^{+}$Th cells, which play a central role in adaptive immune responses, are the predominant viral reservoir in the peripheral blood [50]. To understand the effects of HTLV-1 infection on the functioning of $\mathrm{CD}^{+}{ }^{+} \mathrm{Th}$ cells, it is necessary to discover if, and if so which of the $\mathrm{Th}$ subpopulations is preferentially infected with HTLV-1. Based on their functions, patterns of cytokine secretion, and expression of specific transcription factors and chemokine receptors, $\mathrm{CD} 4{ }^{+} \mathrm{Th}$ cells, which are differentiated from naïve $\mathrm{CD}^{+} \mathrm{T}$ cells, are classified into four major lineages: Th1, Th2, Th17, and Treg cells (Figure 1).

Figure 1. $\mathrm{T}$ cell subsets of $\mathrm{CD}^{+} \mathrm{T}$ helper cells. Th cells are differentiated from naïve $\mathrm{CD}^{+} \mathrm{T}$ cells into 4 major lineages: Th1, Th2, Th17, and T-regulatory (Treg) cells. Each Th subset exhibits characteristic functions, patterns of cytokine secretion, and expression of specific chemokine receptors.

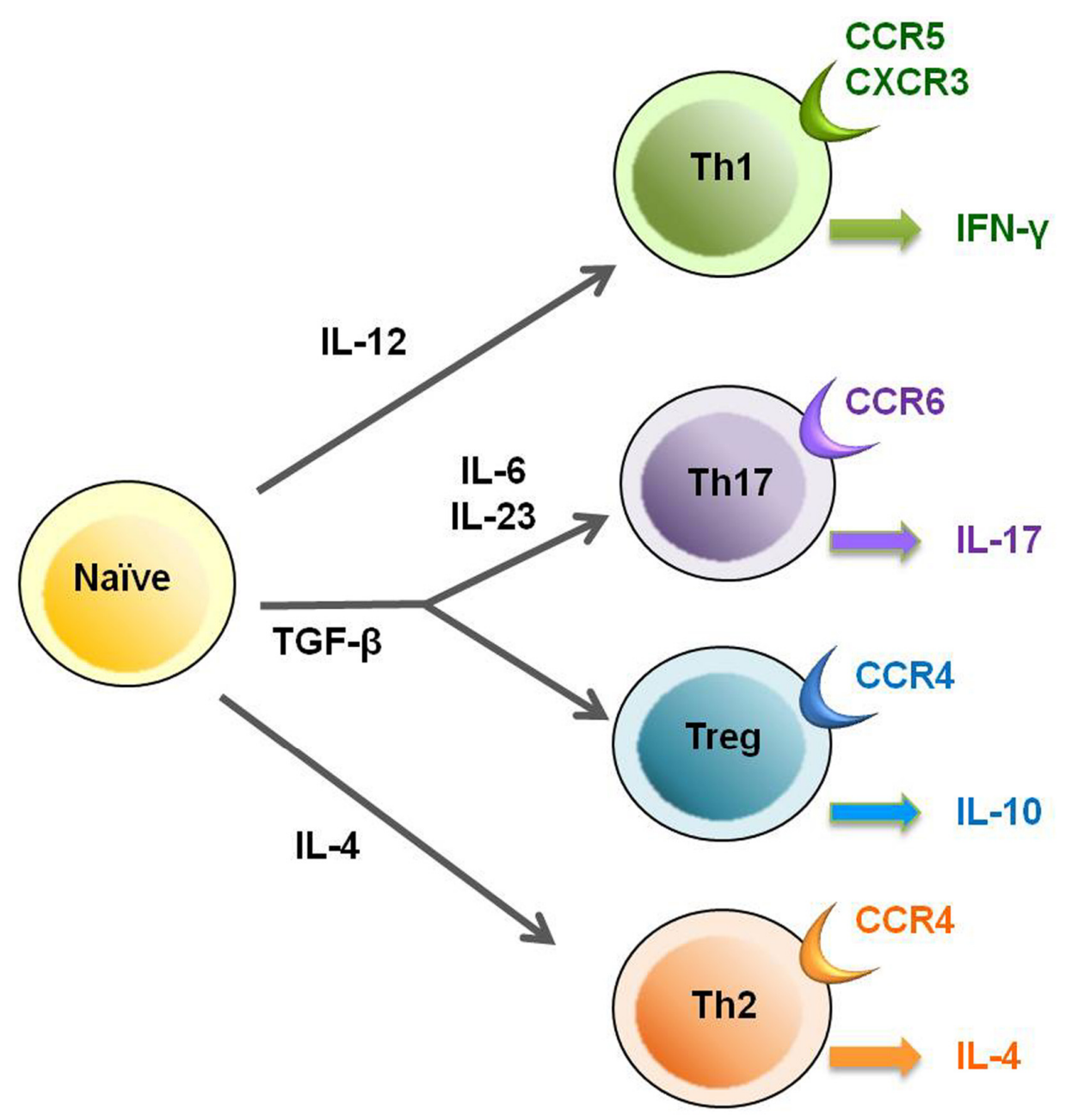

The chemokine receptor CCR4 has recently been found to be expressed on HTLV-1-infected leukemia cells in ATL patients [51]. Because CCR4 is known to be selectively expressed on Treg and Th2 cells [51-53] (Figure 1) and because most ATL cells express high levels of Foxp3, it has been hypothesized that ATL cells may be derived from Treg cells [41]. Although it has been 
demonstrated that $\mathrm{CD} 4^{+} \mathrm{CD} 25^{+} \mathrm{T}$ cells in HAM/TSP patients exhibit reduced Foxp3 expression and Treg suppression [30-33] and that HTLV-1-infected CD4 ${ }^{+} \mathrm{T}$ cells in HAM/TSP patients produce Th1 cytokines (IFN- $\gamma$ ) [16,30], it has also been observed that CCR4 selectively overexpresses on HTLV-1-infected T cells in HAM/TSP patients [54]. Furthermore, the majority of CD ${ }^{+} \mathrm{CD} 25^{+} \mathrm{CCR} 4^{+}$ $\mathrm{T}$ cells have been found to be infected with HTLV-1 and this T cell subset has increased numbers in $\mathrm{HAM}$ /TSP patients [54]. Thus, $\mathrm{CD} 4{ }^{+} \mathrm{CD} 25^{+} \mathrm{CCR} 4^{+} \mathrm{T}$ cells are a major reservoir of HTLV-1-infected $\mathrm{T}$ cells, which are increased in numbers in both HAM/TSP and ATL patients.

\section{HTLV-1 and $\operatorname{Foxp}^{-} \mathrm{CD}^{+} \mathrm{CD}^{+} 5^{+} \mathrm{CCR}^{+} \mathrm{T}$ Cells}

Although CCR4 is known to be selectively expressed on Treg and Th2 cells in healthy individuals, more detailed flow cytometric analysis of Foxp3 expression in $\mathrm{CD} 4^{+} \mathrm{CD} 25^{+} \mathrm{CCR} 4^{+} \mathrm{T}$ cells of HAM/TSP patients demonstrated that the frequency of the Foxp $3^{-}$population was greatly increased in $\mathrm{CD} 4{ }^{+} \mathrm{CD} 25^{+} \mathrm{CCR} 4^{+} \mathrm{T}$ cells [54]. Moreover, analysis of proinflammatory cytokine expression in this Foxp $3{ }^{-} \mathrm{CD} 4^{+} \mathrm{CD} 25^{+} \mathrm{CCR} 4^{+} \mathrm{T}$ cell subset demonstrated that these cells uniquely produced multiple proinflammatory cytokines such as IL-2, IL-17, and few IFN- $\gamma$ in healthy individuals while Foxp $3^{+} \mathrm{CD} 4^{+} \mathrm{CD} 25^{+} \mathrm{CCR} 4^{+} \mathrm{T}$ cells (Treg cells) did not. Furthermore, it was demonstrated that HAM/TSP patients had only few Foxp $3^{+} \mathrm{CD} 4^{+} \mathrm{CD} 25^{+} \mathrm{CCR} 4^{+} \mathrm{T}$ cells that did not produce such cytokines [54]. The Foxp $3^{-} \mathrm{CD} 4^{+} \mathrm{CD} 25^{+} \mathrm{CCR} 4^{+} \mathrm{T}$ cells in HAM/TSP were greater in number and overproduced IFN- $\gamma$ [54]. Further, the proportion of these IFN- $\gamma$-producing Foxp $3^{-} \mathrm{CD} 4{ }^{+} \mathrm{CD} 25^{+} \mathrm{CCR} 4^{+}$ $\mathrm{T}$ cells may have a functional consequence, since the presence of this subpopulation could be correlated with disease activity and severity of HAM/TSP in vivo [54]. Thus, in a CD $4^{+} \mathrm{CD} 25^{+} \mathrm{CCR} 4^{+}$ $\mathrm{T}$ cell population that mainly consists of suppressive $\mathrm{T}$ cell subsets such as Treg and Th2 under healthy conditions, IFN- $\gamma$-producing Foxp $3^{-} \mathrm{CD} 4^{+} \mathrm{CD} 25^{+} \mathrm{CCR} 4^{+} \mathrm{T}$ cells, rarely encountered in healthy individuals, were increased in number and overproduced IFN- $\gamma$ in HAM/TSP patients (Figure 2). We therefore propose to call this IFN- $\gamma^{+} \mathrm{Foxp} 3^{-} \mathrm{CD} 4^{+} \mathrm{CD} 25^{+} \mathrm{CCR} 4^{+} \mathrm{T}$ cell subset $\mathrm{T}_{\mathrm{HAM}}$ cells. Interestingly, increased numbers of Foxp $3{ }^{\text {low }} \mathrm{CD} 4{ }^{+} \mathrm{CD} 25^{+}$memory $\mathrm{T}$ cells, which have cytokine secretion patterns similar to those of $\mathrm{T}_{\text {HAM }}$ cells, have recently been observed in patients with active systemic lupus erythematosus (SLE) [55]. Therefore, it would be of interest to build on this finding by confirming whether this newly defined unique T cell subset, which has been observed in both HAM/TSP and SLE patients, is found in both these patient groups and can be functionally deregulated in other immunological diseases.

Although most $\mathrm{CD} 4^{+} \mathrm{CD} 25^{+} \mathrm{CCR} 4^{+} \mathrm{T}$ cells are infected with HTLV-1 in both HAM/TSP and ATL patients $[54,56]$, the ratio of $\mathrm{T}_{\mathrm{HAM}}$ cells $\left(\mathrm{CCR} 4^{+} \mathrm{Foxp}^{-}\right.$with $\mathrm{IFN}-\gamma$ production) to Treg cells (CCR4 ${ }^{+} \mathrm{Foxp}^{+}$with no cytokine production) in the $\mathrm{CD} 4^{+} \mathrm{CD} 25^{+} \mathrm{CCR} 4^{+} \mathrm{T}$ cell subset has been found to be high in HAM/TSP patients but low in ATL patients [54]. This differential $\mathrm{T}_{\mathrm{HAM}} /$ Treg ratio in HTLV-1-infected $\mathrm{T}$ cells may be associated with the differential immune responses observed between HAM/TSP and ATL patients (Figure 3). ATL patients tend to have very low numbers of Tax-specific $\mathrm{CD}^{+} \mathrm{T}$ cells in peripheral blood mononuclear cells (PBMCs) and to develop opportunistic infections [57,58], while HAM/TSP patients tend to have high numbers of Tax-specific $\mathrm{CD} 8^{+}$CTLs $[11,12,14,59]$. As $\mathrm{CD} 4^{+} \mathrm{CD} 25^{+} \mathrm{T}$ cells with high levels of Foxp3 expression have been reported to have an immunosuppressive function in ATL patients [41-43], the increased number of 
$\mathrm{CD} 4{ }^{+} \mathrm{CD} 25^{+} \mathrm{CCR} 4^{+}$leukemia $\mathrm{T}$ cells with Treg functions observed in ATL patients may contribute to their clinically observed cellular immunodeficiency. However, HAM/TSP patients show very high cellular and humoral immune responses, such as high proportions of Tax-specific $\mathrm{CD}^{+} \mathrm{T}$ cells, as well as cytomegalovirus (CMV)-specific $\mathrm{CD}^{+} \mathrm{T}$ cells in the PBMCs [14,33]; high antibody titer to HTLV-1 [9]; and increased production of proinflammatory cytokines, such as IL-12 and IFN- $\gamma$ [60]. It has been reported that $\mathrm{CD}^{+} \mathrm{CD} 25^{+} \mathrm{T}$ cells with low expression of Foxp3 [30] and HTLV-1 Tax-expressing Foxp ${ }^{+}$Treg cells [61] extracted from HAM/TSP patients exhibit defective immunosuppressive functioning. Moreover, it has been demonstrated that HTLV-1-infected IFN- $\gamma$-overproducing $\mathrm{CD} 4^{+} \mathrm{CD} 25^{+} \mathrm{CCR} 4^{+} \mathrm{Foxp}^{-} \mathrm{T}^{-}$cells $\left(\mathrm{T}_{\mathrm{HAM}}\right.$ cells) increase in number in HAM/TSP patients, and their levels can be correlated with disease severity [54]. Thus, $\mathrm{CD} 4^{+} \mathrm{CD} 25^{+} \mathrm{CCR} 4^{+} \mathrm{T}$ cells with increased proinflammatory functioning, together with a defective Treg compartment $[30-33,54]$, may overcome the regulatory effect of HTLV-1-uninfected Treg cells [61] and at least partly account for the heightened immune response observed in HAM/TSP patients. Collectively, these observations support the hypothesis that an imbalance in the $\mathrm{T}_{\mathrm{HAM}} /$ Treg ratio in HTLV-1-infected $\mathrm{CD} 4{ }^{+} \mathrm{CD} 25^{+} \mathrm{CCR} 4^{+} \mathrm{T}$ cells is an important contributing factor in the immunological differences in host immune response observed between HAM/TSP and ATL patients (Figure 3).

Figure 2. Cellular components of $\mathrm{CD} 4^{+} \mathrm{CD} 25^{+} \mathrm{CCR} 4^{+} \mathrm{T}$ cells in healthy donors and $\mathrm{HAM} / \mathrm{TSP}$ patients. In healthy donors, the $\mathrm{CD}^{+} \mathrm{CD} 25^{+} \mathrm{CCR} 4^{+} \mathrm{T}$ cell population primarily consists of suppressive $\mathrm{T}$ cell subsets, such as Treg and Th2, whereas that of HTLV-1-associated myelopathy/tropical spastic paraparesis (HAM/TSP) patients consists of an increased number of IFN- $\gamma$-producing Foxp $3^{-} \mathrm{CD} 4^{+} \mathrm{CD} 25^{+} \mathrm{CCR} 4^{+} \mathrm{T}$ cells $\left(\mathrm{T}_{\mathrm{HAM}}\right.$ cells).
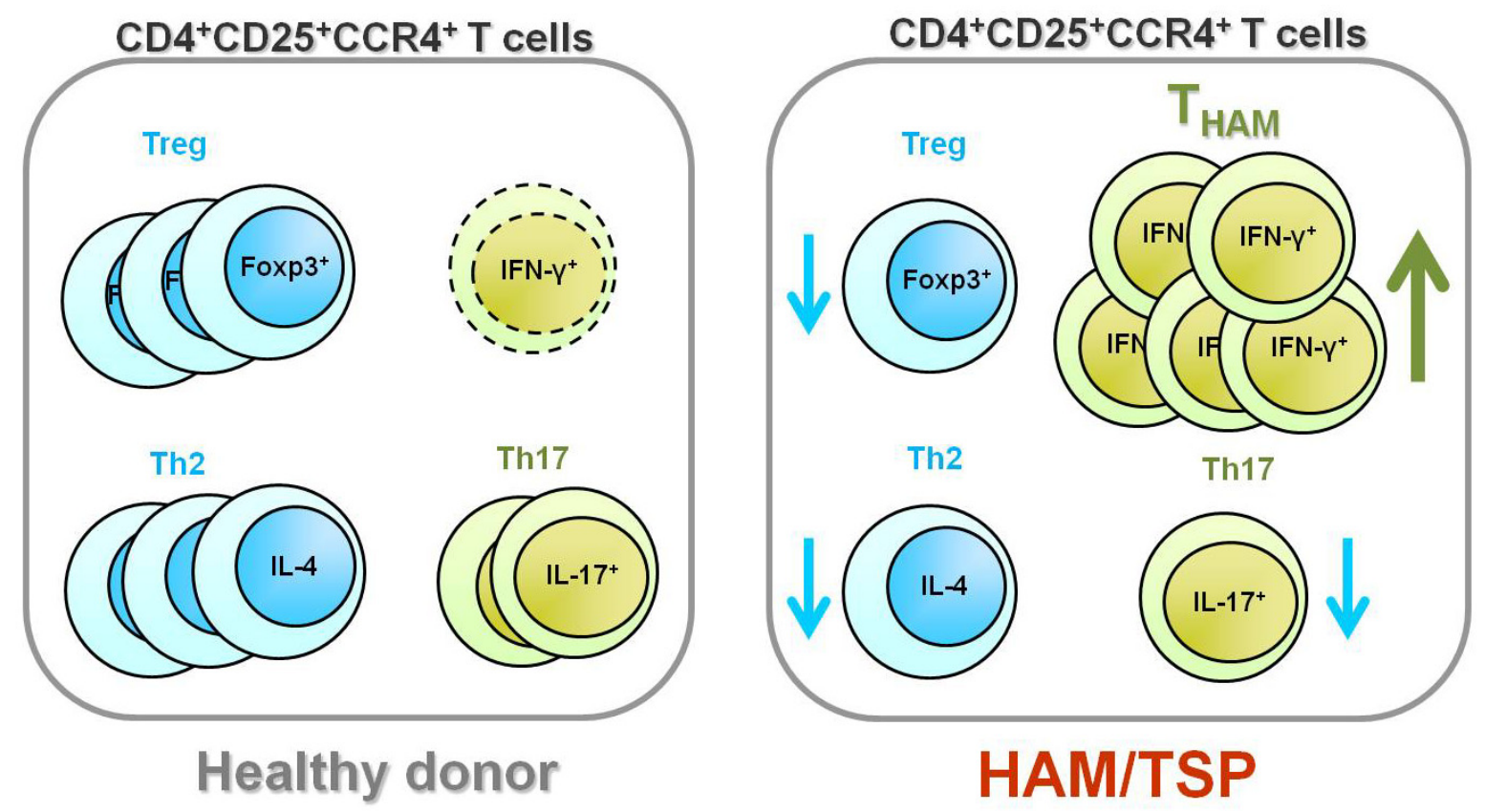
Figure 3. Differential immune responses and $\mathrm{T}_{\mathrm{HAM}} / \mathrm{Treg}$ ratios in $\mathrm{CD} 4^{+} \mathrm{CD} 25^{+} \mathrm{CCR} 4^{+} \mathrm{T}$ cells in HAM/TSP and adult T cell leukemia/lymphoma (ATL) patients.
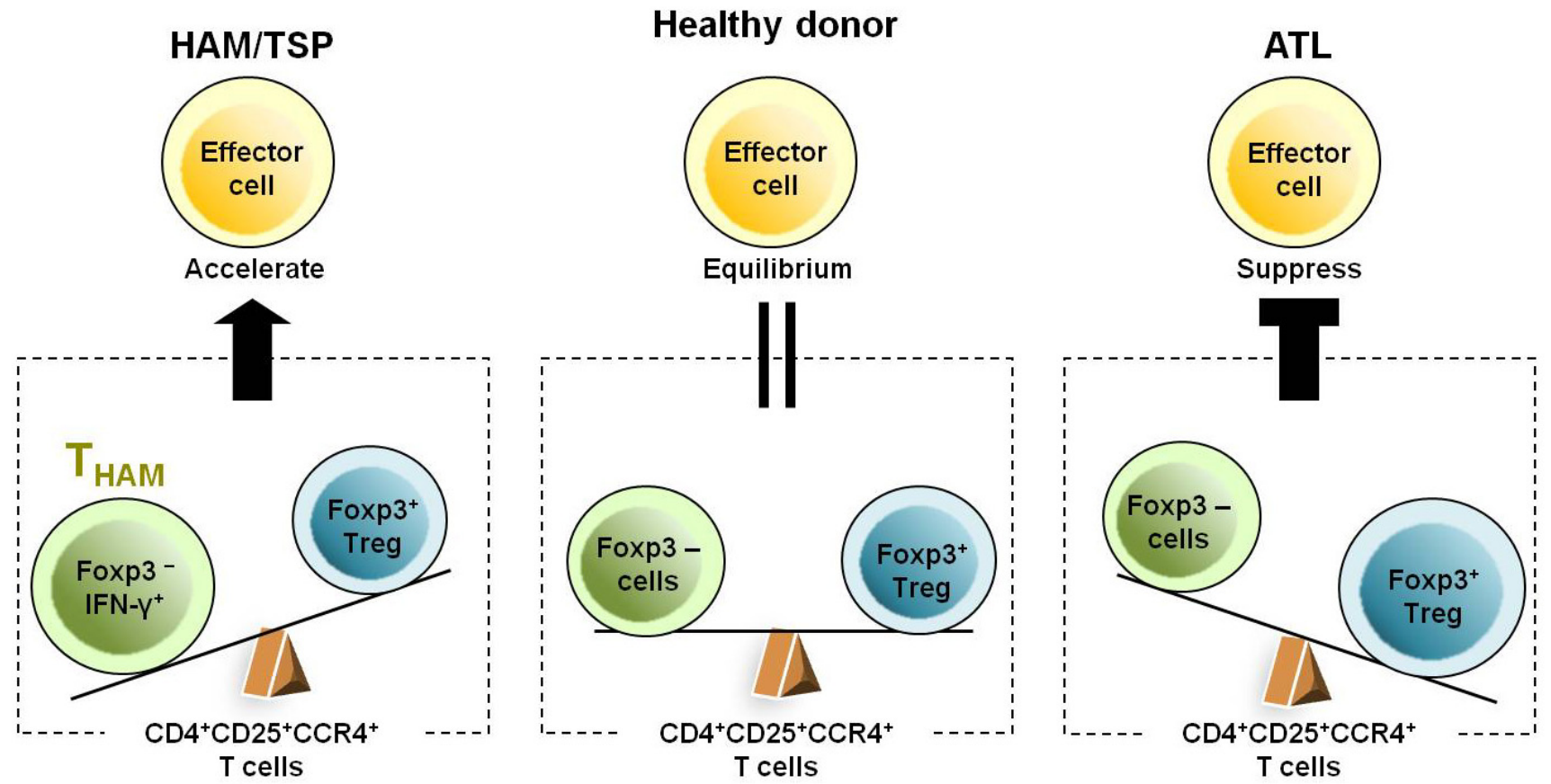

\section{Increased Numbers of $\mathrm{CD}^{+} \mathrm{Foxp3}^{+}$Cells in HAM/TSP Patients}

Recently, it has been reported that the number of $\mathrm{CD}^{+}{ }^{+}$Foxp $3^{+}$cells increases in HTLV-1-infected asymptomatic carriers, and is even higher in patients with HAM/TSP [61]. Although this report initially appears to conflict with the observations described above, it may not. In contrast to the decreased number of $\mathrm{CD}^{+} \mathrm{T}$ cells in patients with human immunodeficiency virus (HIV) infection, the number of HTLV-1 infected $\mathrm{CD}^{+} \mathrm{T}$ cells - most of which are CD4+CD25+CCR4+ $\mathrm{T}$ cells - in $\mathrm{HAM} / \mathrm{TSP}$ patients is greatly increased. Therefore, although the percentage of Foxp $3^{+}$cells among the $\mathrm{CD} 4{ }^{+} \mathrm{CD} 25^{+} \mathrm{CCR} 4^{+} \mathrm{T}$ cells is lower, the overall number of $\mathrm{CD} 4{ }^{+} \mathrm{Foxp} 3^{+}$cells in HAM/TSP patients may be higher than that in healthy donors (Figure 4). Indeed, when we analyzed the number of Foxp $3^{+}$ cells in healthy donors and HAM/TSP patients, we found it to be nearly equivalent between the two groups or slightly higher in HAM/TSP patients [54]. This difference (from slightly high to higher) would depend on the number of HTLV-1-infected CD4 ${ }^{+} \mathrm{T}$ cells in the samples tested. Importantly, Toulza et al. demonstrated that the rate of CTL-mediated lysis was negatively correlated with the number of HTLV-1-Tax ${ }^{-} \mathrm{CD} 4^{+} \mathrm{Foxp}^{+}$cells, but not with the number of $\mathrm{Tax}^{+} \mathrm{CD} 4^{+} \mathrm{Foxp}^{+}$cells [61], again suggesting that HTLV-1-infected Treg cells lose their regulatory function, while HTLV-1-uninfected Treg cells contribute substantially to immune control of HTLV-1 infection. 
Figure 4. Scheme of proportion of each cellular component in $\mathrm{CD} 4^{+} \mathrm{CD} 25^{+} \mathrm{CCR} 4^{+} \mathrm{T}$ cells of healthy donors, asymptomatic carriers (AC), and patients with HAM/TSP or ATL. Although the proportion of Foxp $3^{+}$cells among the $\mathrm{CD} 4{ }^{+} \mathrm{CD} 25^{+} \mathrm{CCR} 4^{+} \mathrm{T}$ cells is lower in HAM/TSP patients, the overall number of $\mathrm{CD} 4^{+} \mathrm{Foxp}^{+}$cells in HAM/TSP patients is higher than that in healthy donors. In ATL patients, the majority of $\mathrm{CD} 4^{+} \mathrm{CD} 25^{+} \mathrm{CCR} 4^{+} \mathrm{T}$ cells are Foxp $3^{+}$cells.

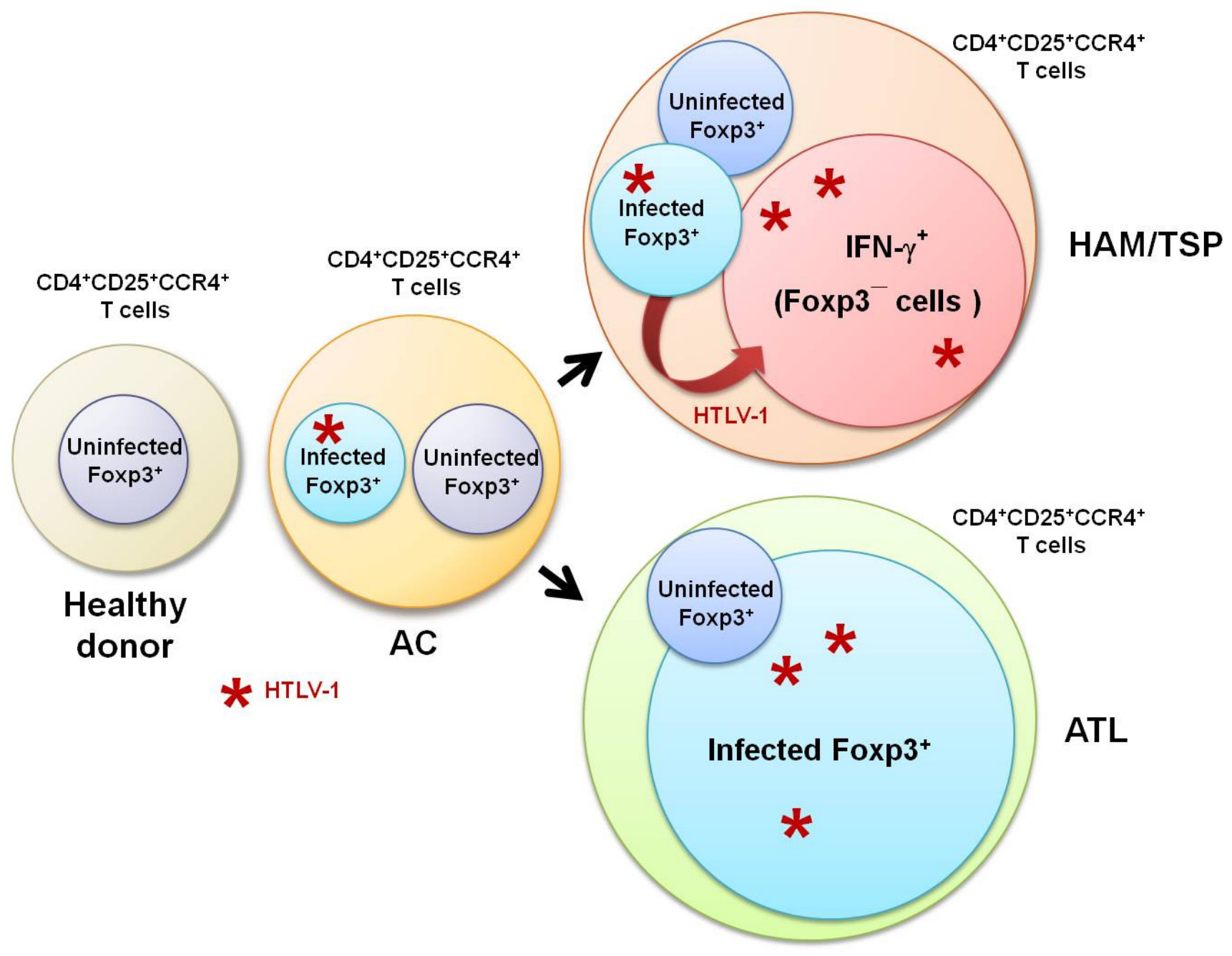

\section{Does the $\mathbf{T}_{\mathrm{HAM}}$ Cell Population Include exFoxp3 ${ }^{+}$Cells? $^{2}$}

According to Hieshima et al.'s recent delineation of the molecular mechanism underlying HTLV-1 tropism to CCR $4^{+} \mathrm{CD} 4^{+} \mathrm{T}$ cells [60], HTLV-1 Tax does not induce expression of CCR4, but Tax does induce expression of CCL22, which is the ligand for CCR4. Therefore, HTLV-1-infected T cells produce CCL22 through Tax and selectively interact with $\mathrm{CCR} 4{ }^{+} \mathrm{CD} 4{ }^{+} \mathrm{T}$ cells, resulting in preferential transmission of HTLV-1 to CCR $4^{+} \mathrm{CD}^{+} \mathrm{T}$ cells (Figure 5). In HTLV-1-seronegative healthy individuals, $\mathrm{CD} 4^{+} \mathrm{CD} 25^{+} \mathrm{CCR} 4^{+} \mathrm{T}$ cell populations primarily consist of suppressive $\mathrm{T}$ cell subsets, such as Treg and Th2 cells [61]. However, as described above, cells of this T cell subset become Th1-like cells that overproduce IFN- $\gamma$ in patients with HAM/TSP, while leukemogenesis develops and maintains the Foxp3 ${ }^{+}$Treg phenotype in ATL patients (Figure 5). 
Figure 5. Differential fate of HTLV-1-infected $\mathrm{CD} 4^{+} \mathrm{CD} 25^{+} \mathrm{CCR} 4^{+} \mathrm{T}$ cells in HAM/TSP and ATL patients. After HTLV-1 infection, $\mathrm{CD} 4^{+} \mathrm{CD} 25^{+} \mathrm{CCR} 4^{+} \mathrm{T}$ cells in HAM/TSP patients, which are primarily Th2 and Treg cells before infection, become IFN- $\gamma^{+}$Foxp $3^{-} \mathrm{T}$ cells ( $\mathrm{T}_{\text {HAM }}$ cells) with high levels of intracellular HTLV-1 tax expression. In ATL patients, leukemogenesis develops and the Foxp $3^{+}$Treg phenotype is maintained.



To determine whether HTLV-1 expression contributes to the differential fate of HTLV-1-infected $\mathrm{CD} 4{ }^{+} \mathrm{CD} 25^{+} \mathrm{CCR} 4^{+} \mathrm{T}$ cells between HAM/TSP and ATL patients, differences in the HTLV-1 proviral load and the HTLV-1 tax mRNA and HTLV-1 HBZ mRNA expression of these populations were analyzed (Figure 6). Although HTLV-1 tax mRNA expression in $\mathrm{CD} 4{ }^{+} \mathrm{CD} 25^{+} \mathrm{CCR} 4^{+} \mathrm{T}$ cells was found to be significantly higher in HAM/TSP patients than in ATL patients, HTLV-1 proviral DNA loads and $H B Z$ mRNA expression levels were found to be equivalent in the two groups [54] (Figure 6). This high HTLV-1 Tax expression in HAM/TSP CD4 ${ }^{+} \mathrm{CD} 25^{+} \mathrm{CCR}^{+} \mathrm{T}$ cells (Foxp3 ${ }^{-}$) and low HTLV-1 Tax expression in ATL CD ${ }^{+} \mathrm{CD} 25^{+} \mathrm{CCR} 4^{+} \mathrm{T}$ cells (Foxp3 ${ }^{+}$) suggests that intracellular HTLV-1 expression may act as a "switch" that directs T cell plasticity from Foxp $3^{+}$Treg cells to IFN- $\gamma^{+}$Foxp $3{ }^{-}$ $\mathrm{T}$ cells. Indeed, a recent report highlighted that loss of Foxp3 in Treg cells and acquisition of IFN- $\gamma$ may result in conversion of suppressor $\mathrm{T}$ cells into highly autoaggressive lymphocytes (exFoxp $3^{+}$ cells), which can contribute to the development of autoimmune conditions [62,63]. These findings support the hypothesis that HTLV-1 tax may be one of the exogenous retrovirus genes responsible for immune dysregulation through its interference in the equilibrium between inflammation and tolerance. 
This hypothesis is currently being tested as a means of elucidating the precise molecular mechanisms by which HTLV-1 influences the fate and function of $\mathrm{CD} 4{ }^{+} \mathrm{CD} 25^{+} \mathrm{CCR} 4^{+} \mathrm{T}$ cells, especially Foxp $3^{+}$ Treg cells. Further research investigating this hypothesis using animal models is required, as is further work to pathologically identify the exFoxp $3^{+}$cells in the spinal cord lesions of HAM/TSP patients.

Figure 6. Increased HTLV-1 tax mRNA expression in $\mathrm{CD} 4{ }^{+} \mathrm{CD} 25^{+} \mathrm{CCR} 4^{+} \mathrm{T}$ cells in $\mathrm{HAM} / \mathrm{TSP}$ patients. The HTLV-1 proviral load in $\mathrm{CD} 4^{+} \mathrm{CD} 25^{+} \mathrm{CCR} 4^{+} \mathrm{T}$ cells from HAM/TSP and ATL patients was quantified by real-time PCR (left panel, $\mathrm{n}=3$ ). Expression levels of HTLV-1 tax mRNA (center panel, HAM/TSP: $\mathrm{n}=4$, ATL: $\mathrm{n}=3$ ) and $H B Z$ mRNA (right panel, $\mathrm{n}=5$ ) in $\mathrm{CD} 4{ }^{+} \mathrm{CD} 25^{+} \mathrm{CCR} 4^{+} \mathrm{T}$ cells from HAM/TSP and ATL patients were quantified by real-time RT-PCR. Data are presented as mean \pm standard error.


\section{Mechanisms Underlying Increased HTLV-1 Tax Expression in HAM/TSP Patients}

As described above, higher levels of HTLV-1 Tax expression have been observed in HAM/TSP patients [11], and a correlation between Tax expression and disease risk [64] has been identified. Both findings, together with experimental evidence [65] and theoretical justification [66] for selective proliferation of HTLV-1 expressing $\mathrm{T}$ cells in vivo, indicate that increased HTLV-1 provirus expression may play an important role in the pathogenesis of HAM/TSP. However, the molecular mechanisms underlying the increased levels of HTLV-1 provirus expression in HAM/TSP patients are not understood. Evidence continues to accumulate that the genomic integration site of HTLV-1 provirus affects the level of provirus expression. Continued accumulation of evidence is aided by the availability of the human genome sequence, which has enabled large-scale research into HTLV-1 integration sites. This research has demonstrated that the provirus integration sites of HTLV-1 in vivo are not randomly distributed within the human genome but rather associated with transcriptionally active regions [67,68]; that the frequent integration into these transcription units is associated with increased levels of provirus expression; and, importantly, that the increased number of integration sites in 
transcription units is associated with HAM/TSP [68]. Future research should endeavor to elucidate the mechanisms underlying the immune dysregulation observed in HAM/TSP patients.

\section{Conclusion}

HTLV-1 initiates persistent infection of CD4 ${ }^{+} \mathrm{T}$ cells and results in the development of HAM/TSP, a chronic neuroinflammatory disorder characterized by very high strong cellular and humoral immune responses. Because a higher viral load in HTLV-1-infected individuals increases the risk of HAM/TSP and is associated with high cellular and humoral immune responses, HTLV-1 infection-induced immune dysregulation may play an important role in the development and pathogenesis of this disease. The recent discovery of Treg cells has provided new opportunities for and generated increased interest in elucidating the mechanisms underlying the induction of immune activation by HTLV-1-infected $\mathrm{T}$ cells. Among the $\mathrm{CD} 4^{+} \mathrm{T}$ helper cell populations that play a central role in adaptive immune responses, the $\mathrm{CD} 4^{+} \mathrm{CD} 25^{+} \mathrm{CCR} 4^{+} \mathrm{T}$ cell population, which primarily consists of suppressive $\mathrm{T}$ cell subsets, such as the Treg and Th2 subsets, in healthy individuals, is the predominant viral reservoir of HTLV-1 in both ATL and HAM/TSP patients. Interestingly, cells of this T cell subset become Th1-like cells, overproducing IFN- $\gamma$ in HAM/TSP patients, while leukemogenesis develops and maintains the Foxp $3^{+}$ Treg phenotype in ATL patients. These results indicate that HTLV-1 may intracellularly induce T cell plasticity from Treg to IFN $-\gamma^{+} \mathrm{T}$ cells, which may contribute to the development of HAM/TSP. As such, these results support the hypothesis that HTLV-1 is one of the exogenous retrovirus genes responsible for immune dysregulation through its interference in the equilibrium maintained among host immune responses. Because the majority of immune disorders are of unknown etiology, the discovery of HTLV-1 and its association with inflammatory conditions has greatly enhanced our understanding of the pathogenic mechanisms underlying organ-specific immune disorders. Further investigation of the mechanism underlying HTLV-1 action in the immune system may result in identification of new molecular pathways that will further elucidate the basic mechanisms underlying immune-mediated disorders.

\section{Conflict of interest}

The authors declare no conflicts of interest.

\section{Acknowledgments}

This work was partially supported by a Grant-in-Aid for Scientific Research from the Ministry of Education, Culture, Sports, Science and Technology; the Japanese Ministry of Health, Labor, and Welfare; the Uehara Memorial Foundation; the Nagao Takeshi Nanbyo Foundation; the Kanagawa Nanbyo Foundation; the Mishima Kaiun Memorial Foundation; the Takeda Science Foundation; the ITSUU Laboratory Research Foundation; the Foundation for Total Health Promotion; and the Sankyo Foundation of Life Science. 


\section{References and Notes}

1. Birmann, B.M.; Breen, E.C.; Stuver, S.; Cranston, B.; Martinez-Maza, O.; Falk, K.I.; Okayama, A.; Hanchard, B.; Mueller, N.; Hisada, M. Population differences in immune marker profiles associated with human T-lymphotropic virus type I infection in Japan and Jamaica. Int. J. Cancer 2009, 124, 614-621.

2. Uchiyama, T.; Yodoi, J.; Sagawa, K.; Takatsuki, K.; Uchino, H. Adult T-cell leukemia: Clinical and hematologic features of 16 cases. Blood 1977, 50, 481-492.

3. Gessain, A.; Barin, F.; Vernant, J.C.; Gout, O.; Maurs, L.; Calender, A.; de The, G. Antibodies to human T-lymphotropic virus type-I in patients with tropical spastic paraparesis. Lancet 1985, 2 , 407-410.

4. Osame, M.; Usuku, K.; Izumo, S.; Ijichi, N.; Amitani, H.; Igata, A.; Matsumoto, M.; Tara, M. HTLV-I associated myelopathy, a new clinical entity. Lancet 1986, 1, 1031-1032.

5. Mochizuki, M.; Watanabe, T.; Yamaguchi, K.; Yoshimura, K.; Nakashima, S.; Shirao, M.; Araki, S.; Takatsuki, K.; Mori, S.; Miyata, N. Uveitis associated with human T-cell lymphotropic virus type I. Am. J. Ophthalmol. 1992, 114, 123-129.

6. Eguchi, K.; Matsuoka, N.; Ida, H.; Nakashima, M.; Sakai, M.; Sakito, S.; Kawakami, A.; Terada, K.; Shimada, H.; Kawabe, Y.; et al. Primary Sjogren's syndrome with antibodies to HTLV-I: Clinical and laboratory features. Ann. Rheum. Dis. 1992, 51, 769-776.

7. Nishioka, K.; Maruyama, I.; Sato, K.; Kitajima, I.; Nakajima, Y.; Osame, M. Chronic inflammatory arthropathy associated with HTLV-I. Lancet 1989, 1, 441.

8. Morgan, O.S.; Rodgers-Johnson, P.; Mora, C.; Char, G. HTLV-1 and polymyositis in Jamaica. Lancet 1989, 2, 1184-1187.

9. Nakagawa, M.; Izumo, S.; Ijichi, S.; Kubota, H.; Arimura, K.; Kawabata, M.; Osame, M. HTLV-I-associated myelopathy: Analysis of 213 patients based on clinical features and laboratory findings. J. Neurovirol. 1995, 1, 50-61.

10. Nagai, M.; Usuku, K.; Matsumoto, W.; Kodama, D.; Takenouchi, N.; Moritoyo, T.; Hashiguchi, S.; Ichinose, M.; Bangham, C.R.; Izumo, S.; et al. Analysis of HTLV-I proviral load in $202 \mathrm{HAM}$ /TSP patients and 243 asymptomatic HTLV-I carriers: High proviral load strongly predisposes to HAM/TSP. J. Neurovirol. 1998, 4, 586-593.

11. Yamano, Y.; Nagai, M.; Brennan, M.; Mora, C.A.; Soldan, S.S.; Tomaru, U.; Takenouchi, N.; Izumo, S.; Osame, M.; Jacobson, S. Correlation of human T-cell lymphotropic virus type 1 (HTLV-1) mRNA with proviral DNA load, virus-specific CD8(+) T cells, and disease severity in HTLV-1-associated myelopathy (HAM/TSP). Blood 2002, 99, 88-94.

12. Nagai, M.; Yamano, Y.; Brennan, M.B.; Mora, C.A.; Jacobson, S. Increased HTLV-I proviral load and preferential expansion of HTLV-I Tax-specific CD8+ T cells in cerebrospinal fluid from patients with HAM/TSP. Ann. Neurol. 2001, 50, 807-812.

13. Nagai, M.; Kubota, R.; Greten, T.F.; Schneck, J.P.; Leist, T.P.; Jacobson, S. Increased activated human T cell lymphotropic virus type I (HTLV-I) Tax11-19-specific memory and effector CD8+ cells in patients with HTLV-I-associated myelopathy/tropical spastic paraparesis: Correlation with HTLV-I provirus load. J. Infect. Dis. 2001, 183, 197-205. 
14. Jacobson, S.; Shida, H.; McFarlin, D.E.; Fauci, A.S.; Koenig, S. Circulating CD8+ cytotoxic T lymphocytes specific for HTLV-I pX in patients with HTLV-I associated neurological disease. Nature 1990, 348, 245-248.

15. Kubota, R.; Kawanishi, T.; Matsubara, H.; Manns, A.; Jacobson, S. HTLV-I specific IFN-gamma+ CD8+ lymphocytes correlate with the proviral load in peripheral blood of infected individuals. J. Neuroimmunol. 2000, 102, 208-215.

16. Hanon, E.; Goon, P.; Taylor, G.P.; Hasegawa, H.; Tanaka, Y.; Weber, J.N.; Bangham, C.R. High production of interferon gamma but not interleukin-2 by human T-lymphotropic virus type I-infected peripheral blood mononuclear cells. Blood 2001, 98, 721-726.

17. Vine, A.M.; Heaps, A.G.; Kaftantzi, L.; Mosley, A.; Asquith, B.; Witkover, A.; Thompson, G.; Saito, M.; Goon, P.K.; Carr, L.; et al. The role of CTLs in persistent viral infection: Cytolytic gene expression in CD8+ lymphocytes distinguishes between individuals with a high or low proviral load of human T cell lymphotropic virus type 1. J. Immunol. 2004, 173, 5121-5129.

18. Iwakura, Y.; Tosu, M.; Yoshida, E.; Takiguchi, M.; Sato, K.; Kitajima, I.; Nishioka, K.; Yamamoto, K.; Takeda, T.; Hatanaka, M.; et al. Induction of inflammatory arthropathy resembling rheumatoid arthritis in mice transgenic for HTLV-I. Science 1991, 253, 1026-1028.

19. Nakamaru, Y.; Ishizu, A.; Ikeda, H.; Sugaya, T.; Fugo, K.; Higuchi, M.; Yamazaki, H.; Yoshiki, T. Immunological hyperresponsiveness in HTLV-I LTR-env-pX transgenic rats: A prototype animal model for collagen vascular and HTLV-I-related inflammatory diseases. Pathobiology 2001, 69, 11-18.

20. Aono, H.; Fujisawa, K.; Hasunuma, T.; Marriott, S.J.; Nishioka, K. Extracellular human T cell leukemia virus type I tax protein stimulates the proliferation of human synovial cells. Arthritis Rheum. 1998, 41, 1995-2003.

21. Siekevitz, M.; Feinberg, M.B.; Holbrook, N.; Wong-Staal, F.; Greene, W.C. Activation of interleukin 2 and interleukin 2 receptor (Tac) promoter expression by the trans-activator (tat) gene product of human T-cell leukemia virus, type I. Proc. Natl. Acad. Sci. U. S. A. 1987, 84, 5389-5393.

22. Cross, S.L.; Feinberg, M.B.; Wolf, J.B.; Holbrook, N.J.; Wong-Staal, F.; Leonard, W.J. Regulation of the human interleukin-2 receptor alpha chain promoter: Activation of a nonfunctional promoter by the transactivator gene of HTLV-I. Cell 1987, 49, 47-56.

23. Azimi, N.; Brown, K.; Bamford, R.N.; Tagaya, Y.; Siebenlist, U.; Waldmann, T.A. Human T cell lymphotropic virus type I Tax protein trans-activates interleukin 15 gene transcription through an NF-kappaB site. Proc. Natl. Acad. Sci. U. S. A. 1998, 95, 2452-2457.

24. Mariner, J.M.; Lantz, V.; Waldmann, T.A.; Azimi, N. Human T cell lymphotropic virus type I Tax activates IL-15R alpha gene expression through an NF-kappa B site. J. Immunol. 2001, 166, 2602-2609.

25. Waldmann, T.A. The biology of interleukin-2 and interleukin-15: Implications for cancer therapy and vaccine design. Nat. Rev. Immunol. 2006, 6, 595-601.

26. Sakaguchi, S.; Sakaguchi, N.; Asano, M.; Itoh, M.; Toda, M. Immunologic self-tolerance maintained by activated T cells expressing IL-2 receptor alpha-chains (CD25). Breakdown of a single mechanism of self-tolerance causes various autoimmune diseases. J. Immunol. 1995, 155, 1151-1164. 
27. Hori, S.; Nomura, T.; Sakaguchi, S. Control of regulatory T cell development by the transcription factor Foxp3. Science 2003, 299, 1057-1061.

28. Sakaguchi, S.; Yamaguchi, T.; Nomura, T.; Ono, M. Regulatory T cells and immune tolerance. Cell 2008, 133, 775-787.

29. Yamano, Y.; Cohen, C.J.; Takenouchi, N.; Yao, K.; Tomaru, U.; Li, H.C.; Reiter, Y.; Jacobson, S. Increased expression of human T lymphocyte virus type I (HTLV-I) Tax11-19 peptide-human histocompatibility leukocyte antigen $\mathrm{A} * 201$ complexes on CD4+ CD25+ T Cells detected by peptide-specific, major histocompatibility complex-restricted antibodies in patients with HTLV-Iassociated neurologic disease. J. Exp. Med. 2004, 199, 1367-1377.

30. Yamano, Y.; Takenouchi, N.; Li, H.C.; Tomaru, U.; Yao, K.; Grant, C.W.; Maric, D.A.; Jacobson, S. Virus-induced dysfunction of CD4+CD25+ T cells in patients with HTLV-Iassociated neuroimmunological disease. J. Clin. Invest. 2005, 115, 1361-1368.

31. Oh, U.; Grant, C.; Griffith, C.; Fugo, K.; Takenouchi, N.; Jacobson, S. Reduced Foxp3 protein expression is associated with inflammatory disease during human $\mathrm{t}$ lymphotropic virus type 1 Infection. J. Infect. Dis. 2006, 193, 1557-1566.

32. Michaelsson, J.; Barbosa, H.M.; Jordan, K.A.; Chapman, J.M.; Brunialti, M.K.; Neto, W.K.; Nukui, Y.; Sabino, E.C.; Chieia, M.A.; Oliveira, A.S.; et al. The frequency of CD127low expressing $\mathrm{CD} 4+\mathrm{CD} 25$ high $\mathrm{T}$ regulatory cells is inversely correlated with human $\mathrm{T}$ lymphotrophic virus type-1 (HTLV-1) proviral load in HTLV-1-infection and HTLV-1-associated myelopathy/tropical spastic paraparesis. BMC Immunol. 2008, 9, 41.

33. Hayashi, D.; Kubota, R.; Takenouchi, N.; Tanaka, Y.; Hirano, R.; Takashima, H.; Osame, M.; Izumo, S.; Arimura, K. Reduced Foxp3 expression with increased cytomegalovirus-specific CTL in HTLV-I-associated myelopathy. J. Neuroimmunol. 2008, 200, 115-124.

34. Ramirez, J.M.; Brembilla, B.N.; Sorg, O.; Chicheportiche, R.; Matthes, T.; Dayer, J.M.; Saurat, J.H.; Roosnek, E.; Chizzolini, C. Activation of the aryl hydrocarbon receptor reveals distinct requirements for IL-22 and IL-17 production by human T helper cells. Eur. J. Immunol. 2010, 40, 2450-2459.

35. Grant, C.; Oh, U.; Yao, K.; Yamano, Y.; Jacobson, S. Dysregulation of TGF-beta signaling and regulatory and effector T-cell function in virus-induced neuroinflammatory disease. Blood 2008, $111,5601-5609$.

36. Ohsugi, E.; KUmasaka, T. Low CD4/CD8 T-cell ratio associated with inflammatory arthropathy in human T-cell leukemia virus type I Tax transgenic mice. PLoS ONE 2011, 6, e18518.

37. Saito, M.; Matsuzaki, T.; Satou, Y.; Yasunaga, J.; Saito, K.; Arimura, K.; Matsuoka, M.; Ohara, Y. In vivo expression of the HBZ gene of HTLV-1 correlates with proviral load, inflammatory markers and disease severity in HTLV-1 associated myelopathy/tropical spastic paraparesis (HAM/TSP). Retrovirology 2009, 6, 19.

38. Satou, Y.; Yasunaga, J.; Zhao, T.; Yoshida, M.; Miyazato, P.; Takai, K.; Shimizu, K.; Ohshima, K.; Green, P.L.; Ohkura, N.; et al. HTLV-1 bZIP factor induces T-cell lymphoma and systemic inflammation in vivo. PLoS Pathog. 2011, 7, e1001274.

39. Karube, K.; Ohshima, K.; Tsuchiya, T.; Yamaguchi, T.; Kawano, R.; Suzumiya, J.; Utsunomiya, A.; Harada, M.; Kikuchi, M. Expression of FoxP3, a key molecule in CD4CD25 regulatory T cells, in adult T-cell leukaemia/lymphoma cells. Br. J. Haematol. 2004, 126, 81-84. 
40. Roncador, G.; Garcia, J.F.; Maestre, L.; Lucas, E.; Menarguez, J.; Ohshima, K.; Nakamura, S.; Banham, A.H.; Piris, M.A. FOXP3, a selective marker for a subset of adult T-cell leukaemia/lymphoma. Leukemia 2005, 19, 2247-2253.

41. Kohno, T.; Yamada, Y.; Akamatsu, N.; Kamihira, S.; Imaizumi, Y.; Tomonaga, M.; Matsuyama, T. Possible origin of adult T-cell leukemia/lymphoma cells from human $\mathrm{T}$ lymphotropic virus type-1-infected regulatory T cells. Cancer Sci. 2005, 96, 527-533.

42. Chen, S.; Ishii, N.; Ine, S.; Ikeda, S.; Fujimura, T.; Ndhlovu, L.C.; Soroosh, P.; Tada, K.; Harigae, H.; Kameoka, J.; et al. Regulatory T cell-like activity of Foxp3+ adult T cell leukemia cells. Int. Immunol. 2006, 18, 269-277.

43. Matsubar, Y.; Hori, T.; Morita, R.; Sakaguchi, S.; Uchiyama, T. Delineation of immunoregulatory properties of adult T-cell leukemia cells. Int. J. Hematol. 2006, 84, 63-69.

44. Shimauchi, T.; Kabashima, K.; Tokura, Y. Adult T-cell leukemia/lymphoma cells from blood and skin tumors express cytotoxic T lymphocyte-associated antigen-4 and Foxp3 but lack suppressor activity toward autologous CD8+ T cells. Cancer Sci. 2008, 99, 98-106.

45. Koyanagi, Y.; Itoyama, Y.; Nakamura, N.; Takamatsu, K.; Kira, J.; Iwamasa, T.; Goto, I.; Yamamoto, N. In vivo infection of human T-cell leukemia virus type $\mathrm{I}$ in non-T cells. Virology 1993, 196, 25-33.

46. Nagai, M.; Brennan, M.B.; Sakai, J.A.; Mora, C.A.; Jacobson, S. CD8(+) T cells are an in vivo reservoir for human T-cell lymphotropic virus type I. Blood 2001, 98, 1858-1861.

47. Jones, K.S.; Petrow-Sadowski, C.; Huang, Y.K.; Bertolette, D.C.; Ruscetti, F.W. Cell-free HTLV-1 infects dendritic cells leading to transmission and transformation of CD4(+) T cells. Nat. Med. 2008, 14, 429-436.

48. Enose-Akahata, Y.; Oh, U.; Grant, C.; Jacobson, S. Retrovirally induced CTL degranulation mediated by IL-15 expression and infection of mononuclear phagocytes in patients with HTLV-I-associated neurologic disease. Blood 2008, 112, 2400-2410.

49. Azakami, K.; Sato, T.; Araya, N.; Utsunomiya, A.; Kubota, R.; Suzuki, K.; Hasegawa, D.; Izumi, T.; Fujita, H.; Aratani, S.; et al. Severe loss of invariant NKT cells exhibiting anti-HTLV-1 activity in patients with HTLV-1-associated disorders. Blood 2009, 114, 3208-3215.

50. Richardson, J.H.; Edwards, A.J.; Cruickshank, J.K.; Rudge, P.; Dalgleish, A.G. In vivo cellular tropism of human T-cell leukemia virus type 1. J. Virol. 1990, 64, 5682-5687.

51. Yoshie, O.; Fujisawa, R.; Nakayama, T.; Harasawa, H.; Tago, H.; Izawa, D.; Hieshima, K.; Tatsumi, Y.; Matsushima, K.; Hasegawa, H.; et al. Frequent expression of CCR4 in adult T-cell leukemia and human T-cell leukemia virus type 1-transformed T cells. Blood 2002, 99, $1505-1511$.

52. Imai, T.; Nagira, M.; Takagi, S.; Kakizaki, M.; Nishimura, M.; Wang, J.; Gray, P.W.; Matsushima, K.; Yoshie, O. Selective recruitment of CCR4-bearing Th2 cells toward antigen-presenting cells by the $\mathrm{CC}$ chemokines thymus and activation-regulated chemokine and macrophage-derived chemokine. Int. Immunol. 1999, 11, 81-88.

53. Iellem, A.; Mariani, M.; Lang, R.; Recalde, H.; Panina-Bordignon, P.; Sinigaglia, F.; D'Ambrosio, D. Unique chemotactic response profile and specific expression of chemokine receptors CCR4 and CCR8 by $\mathrm{CD} 4(+) \mathrm{CD} 25(+)$ regulatory T cells. J. Exp. Med. 2001, 194, $847-853$. 
54. Yamano, Y.; Araya, N.; Sato, T.; Utsunomiya, A.; Azakami, K.; Hasegawa, D.; Izumi, T.; Fujita, H.; Aratani, S.; Yagishita, N.; et al. Abnormally high levels of virus-infected IFN-gamma+ CCR4+ CD4+ CD25+ T cells in a retrovirus-associated neuroinflammatory disorder. PLoS ONE 2009, 4, e6517.

55. Miyara, M.; Yoshioka, Y.; Kitoh, A.; Shima, T.; Wing, K.; Niwa, A.; Parizot, C.; Taflin, C.; Heike, T.; Valeyre, D.; et al. Functional delineation and differentiation dynamics of human CD4+ T cells expressing the FoxP3 transcription factor. Immunity 2009, 30, 899-911.

56. Yoshie, O. Expression of CCR4 in adult T-cell leukemia. Leuk. Lymphoma 2005, 46, 185-190.

57. Kannagi, M. Immunologic control of human T-cell leukemia virus type I and adult T-cell leukemia. Int. J. Hematol. 2007, 86, 113-117.

58. Matsuoka, M. Human T-cell leukemia virus type I (HTLV-I) infection and the onset of adult T-cell leukemia (ATL). Retrovirology 2005, 2, 27.

59. Kubota, R.; Nagai, M.; Kawanishi, T.; Osame, M.; Jacobson, S. Increased HTLV type 1 tax specific CD8+ cells in HTLV type 1-asociated myelopathy/tropical spastic paraparesis: Correlation with HTLV type 1 proviral load. AIDS Res. Hum. Retroviruses 2000, 16, 1705-1709.

60. Furuya, T.; Nakamura, T.; Fujimoto, T.; Nakane, S.; Kambara, C.; Shirabe, S.; Hamasaki, S.; Motomura, M.; Eguchi, K. Elevated levels of interleukin-12 and interferon-gamma in patients with human T lymphotropic virus type I-associated myelopathy. J. Neuroimmunol. 1999, 95, 185-189.

61. Toulza, F.; Heaps, A.; Tanaka, Y.; Taylor, G.P.; Bangham, C.R. High frequency of CD4+FoxP3+ cells in HTLV-1 infection: Inverse correlation with HTLV-1-specific CTL response. Blood 2008, 111, 5047-5053.

62. Zhou, X.; Bailey-Bucktrout, S.L.; Jeker, L.T.; Penaranda, C.; Martinez-Llordella, M.; Ashby, M.; Nakayama, M.; Rosenthal, W.; Bluestone, J.A. Instability of the transcription factor Foxp3 leads to the generation of pathogenic memory T cells in vivo. Nat. Immunol. 2009, 10, 1000-1007.

63. Tsuji, M.; Komatsu, N.; Kawamoto, S.; Suzuki, K.; Kanagawa, O.; Honjo, T.; Hori, S.; Fagarasan, S. Preferential generation of follicular B helper T cells from Foxp3 + T cells in gut Peyer's patches. Science 2009, 323, 1488-1492.

64. Asquith, B.; Mosley, A.J.; Heaps, A.; Tanaka, Y.; Taylor, G.P.; McLean, A.R.; Bangham, C.R. Quantification of the virus-host interaction in human $\mathrm{T}$ lymphotropic virus $\mathrm{I}$ infection. Retrovirology 2005, 2, 75.

65. Asquith, B.; Zhang, Y.; Mosley, A.J.; de Lara, C.M.; Wallace, D.L.; Worth, A.; Kaftantzi, L.; Meekings, K.; Griffin, G.E.; Tanaka, Y.; et al. In vivo T lymphocyte dynamics in humans and the impact of human T-lymphotropic virus 1 infection. Proc. Natl. Acad. Sci. U. S. A. 2007, 104, 8035-8040.

66. Asquith, B.; Bangham, C.R. How does HTLV-I persist despite a strong cell-mediated immune response? Trends Immunol. 2008, 29, 4-11.

67. Derse, D.; Crise, B.; Li, Y.; Princler, G.; Lum, N.; Stewart, C.; McGrath, C.F.; Hughes, S.H.; Munroe, D.J.; Wu, X. Human T-cell leukemia virus type 1 integration target sites in the human genome: Comparison with those of other retroviruses. J. Virol. 2007, 81, 6731-6741. 
68. Meekings, K.N.; Leipzig, J.; Bushman, F.D.; Taylor, G.P.; Bangham, C.R. HTLV-1 integration into transcriptionally active genomic regions is associated with proviral expression and with HAM/TSP. PLoS Pathog. 2008, 4, e1000027.

(C) 2011 by the authors; licensee MDPI, Basel, Switzerland. This article is an open access article distributed under the terms and conditions of the Creative Commons Attribution license (http://creativecommons.org/licenses/by/3.0/). 